\title{
Cyclic AMP and Sodium Transport
}

\author{
QUANTITATIVE AND TEMPORAL RELATIONSHIPS \\ IN TOAD URINARY BLADDER
}

\author{
Victor S. SAPIRSTEIN and WALter N. ScotT \\ From the Departments of Ophthalmology and Physiology, Mount Sinai School \\ of Medicine of The City University of New York, New York 10029
}

A B S T R A C T The effects of oxytocin upon tissue cAMP content and short-circuit current (SCC) were measured in the urinary bladder of the toad, Bufo marinus. Tissue cAMP levels doubled before any increment in SCC was observed, the two hormone responses were quantitatively related, and a threshold level for an effect of cAMP upon sodium transport was demonstrated. The period of time over which cAMP levels continued to rise after the threshold level had been attained seemed invariant with hormone concentration. The rate at which cAMP levels rose increased with hormone concentration yielding hormone concentration-dependent maximal levels. The decay of cAMP levels was delayed when sodium influx was curtailed, suggesting a sodium-regulatory effect upon tissue cAMP levels.

\section{INTRODUCTION}

Adenosine $3^{\prime}, 5^{\prime}$-monophosphate (cAMP) has been implicated as the "second messenger" for hormone effects initiated by interaction of a number of hormones with the cell membranes of their respective target tissue (1). In several tissues the temporal and quantitative response of the tissue cAMP levels to hormone have been determined and, as required by the "second messenger" hypothesis (2), the increase in tissue cAMP precedes the

Dr. Scott is an Established Investigator of the American Heart Association.

Received for publication 15 February 1973 and in revised form 25 June 1973. physiologic effect of the hormone upon the tissue, and the extent of the hormone effect is directly related to the magnitude of the cAMP increment.

Oxytocin, arginine vasopressin, and related peptides cause an increase in the permeability of the toad bladder to water (3) and an increase in the rate at which sodium is transported from the mucosal to serosal surfaces (4). These effects can also be obtained by phosphodiesterase inhibitors, e.g., caffeine and theophylline, and by the addition of exogenous cAMP (5). However, previous studies of toad bladder cAMP following the addition of hormone have shown only modest increases in the cyclic nucleotide (6). The degree of elevation of tissue cAMP reported is not consonant with the striking physiologic effects evoked by the neurohypophyseal hormones nor with the large increase in cAMP reported in other instances in which cAMP is presumed to mediate and amplify hormonal stimuli (7). Nor is there any evidence that the physiologic response is temporally dependent upon the precedent increase in tissue cAMP. The purposes of this study were $(a)$ to examine the time course of the change in tissue cAMP content in response to oxytocin, $(b)$ to relate these changes to the stimulation of sodium transport and $(c)$ to determine the quantitative relations between the tissue cAMP and sodium transport.

\section{METHODS}

Bufo marinus of Dominican origin were obtained from Lemberger Co. (Oshkosh, Wisc.) and kept at room temperature in moist soil. Toads were doubly pithed and the bladders dissected and rinsed in Ringer's solution. One hemi-bladder 


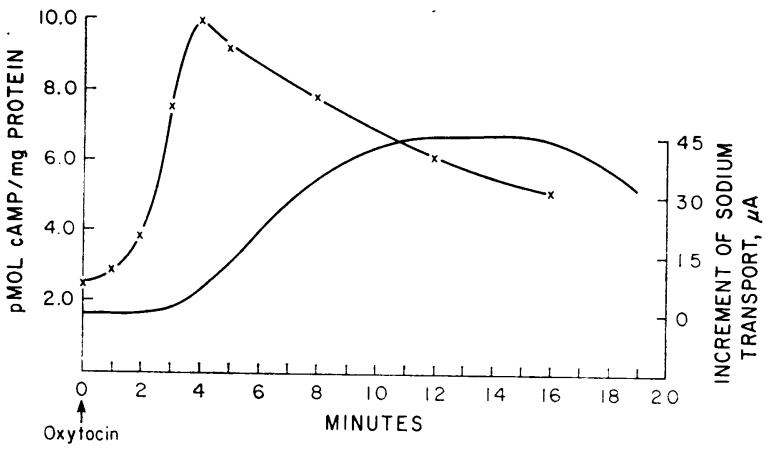

Figure 1 A typical experiment showing the response of tissue cyclic AMP $(\times-\times)$ and SCC $(-)$ to the addition of oxytocin $\left(2 \times 10^{-8} \mathrm{M}\right)$ to the solution bathing the serosal surface of the toad bladder. The bladders were bathed in Ringer's solution ( $\mathrm{pH} 7.8$ ) whose composition was $\mathrm{NaCl}, 85 \mathrm{mM}$; $\mathrm{NaHCO}_{3}, 17.5 \mathrm{mM}$; KCl, $4 \mathrm{mM}$; $\mathrm{MgSO}_{4}$, $0.8 \mathrm{mM} ; \mathrm{KH}_{2} \mathrm{PO}_{4}, 0.8 \mathrm{mM} ; \mathrm{CaCl}_{2}, 1 \mathrm{mM}$; and glucose, 11 $\mathrm{mM}$. The SCC in one hemi-bladder began to increase at approximately $2.5 \mathrm{~min}$, and peaked at $12 \mathrm{~min}$. Tissue cAMP in the matching hemi-bladder, measured at the indicated intervals, began to rise approximately $1 \frac{1}{2} \mathrm{~min}$ after the addition of oxytocin, reached a peak at approximately $4 \mathrm{~min}$, and then began to fall.

from each animal was mounted in a Lucite chamber with the serosal and mucosal surfaces bathed in Ringer's solution. The SCC was monitored continuously by conventional techniques across $1.5 \mathrm{~cm}^{2}$ of tissue except for brief intervals in which the spontaneous potential difference was measured (8). After an equilibration period of $1 \mathrm{~h}$, hormone was added to the serosal bath and the SCC measured for $30 \mathrm{~min}$. The paired hemi-bladder was carefully cut into 12 pieces of approximately equal size and incubated in a flask containing $5 \mathrm{ml}$ of Ringer's solution. The pieces of tissue were treated with the same concentration of oxytocin as the hemi-bladder in the Lucite chamber and removed at the indicated times following addition of hormone. Cyclic AMP content in the tissues was measured by the radioimmunoassay method of Steiner, Kipnis, Utiger, and Parker (9) using commercially prepared materials (Collaborative Research, Cambridge, Mass.). The tissue sections were placed in $1.0 \mathrm{ml}$ of $0.05 \mathrm{M}$ acetate buffer $(\mathrm{pH} 6.2)$ at $100^{\circ} \mathrm{C}$. After $5 \mathrm{~min}$ the tissues were disrupted by sonication and centrifuged for $20 \mathrm{~min}$ at $5,000 \mathrm{rpm}$, and a $0.3 \mathrm{ml}$ aliquot of the supernate was used for cAMP determinations. The labeled ligand was [succinyl$\left.{ }^{125} \mathrm{I}\right]$-cAMP tyrosine methyl ester $(600 \mathrm{Ci} / \mathrm{mmol})$. The cAMP antibody complex was precipitated with goat antirabbit IgG using normal rabbit serum as carrier, collected by filtration (Millipore filter, $0.45 \mu \mathrm{m}$ ), and counted in a Nuclear-Chicago scintillation counter (Nuclear-Chicago Corp., Des Plaines, Ill.). The necks of 8-10 hemi-bladders were each tied to the outlet of a Luer-lock syringe, filled with and immersed in $\mathrm{Ca}^{2+}$-free Ringer's solution containing $2 \mathrm{mM}$ EDTA, and incubated for $40-60 \mathrm{~min}$ at room temperature. The intraluminal fluid containing the disaggregated mucosal cells was collected and centrifuged. The sedimented cells were resuspended in Ringer's solution (containing $1 \mathrm{mM} \mathrm{Ca}{ }^{2+}$ ), oxytocin was added, and aliquots of cells were removed at intervals for measurement of cAMP and protein (biuret).

\section{RESULTS AND DISCUSSION}

Fig. 1 shows a typical experiment. The addition of a submaximal dose of oxytocin $\left(2 \times 10^{-8} \mathrm{M}\right)$ to the bladder

TABLE I

Effects of Oxytocin upon Toad Bladder Cyclic AMP and Short-Circuit Current

\begin{tabular}{|c|c|c|c|c|c|c|}
\hline \multirow[b]{2}{*}{ Exp. no. } & \multirow[b]{2}{*}{ Oxytocin } & \multicolumn{3}{|c|}{ Tissue cyclic AMP } & \multicolumn{2}{|c|}{$\begin{array}{c}\text { Increment of sodium } \\
\text { transport }\end{array}$} \\
\hline & & $\begin{array}{l}\text { Time to } \\
\text { doubling of } \\
\text { basal conc. }\end{array}$ & $\begin{array}{l}\text { Maximum } \\
\text { increment }\end{array}$ & $\begin{array}{l}\text { Time to } \\
\text { peak level } \\
\text { of cAMP }\end{array}$ & $\begin{array}{c}\text { Time to } \\
\text { onset }\end{array}$ & $\begin{array}{l}\text { Maximum } \\
\text { increment }\end{array}$ \\
\hline & $M \times 10^{-9}$ & $\min$ & pmol/mg protein & $\min$ & $\min$ & $\mu A$ \\
\hline 1 & 1.25 & - & 2.94 & 7.0 & - & - \\
\hline 2 & 2.5 & - & 1.87 & 7.0 & - & - \\
\hline 3 & 2.5 & 一 & 2.41 & 6.5 & $\ldots$ & - \\
\hline 4 & 2.5 & 4.5 & 4.01 & 6.0 & 4.3 & 8 \\
\hline 5 & 2.5 & 5.0 & 3.67 & 6.0 & 4.5 & 6 \\
\hline 6 & 5 & 4.5 & 4.01 & 6.0 & 4.5 & 6 \\
\hline 7 & 5 & 4.5 & 3.51 & 6.0 & 4.5 & 5 \\
\hline 8 & 5 & 2.8 & 6.84 & 4.0 & 3.0 & 32 \\
\hline 9 & 5 & 2.8 & 6.34 & 4.0 & 3.0 & 38 \\
\hline $10-13$ & 10 & 3.0 & $6.31 \pm 0.43$ & 4.5 & 3.5 & $31 \pm 3.2$ \\
\hline $14-17$ & 20 & 2.5 & $9.17 \pm 0.73$ & 4.0 & 2.5 & $46 \pm 4.4$ \\
\hline $18-21$ & 40 & 1.5 & $14.45 \pm 1.0$ & 3.0 & 1.5 & $64 \pm 4.4$ \\
\hline
\end{tabular}

* The basal cyclic AMP concentration was $3.4 \pm 0.18 \mathrm{pmol} / \mathrm{mg}$ protein (mean $\pm \mathrm{SEM} ; n=20$ ); the basal short-circuit current was $70.0 \pm 8.4 \mu \mathrm{A} / 1.5 \mathrm{~cm}^{2}$. At those concentrations of oxytocin in which the SCC response was absent or minimal, the results of each experiment are given; in the experiments that were clearly suprathreshold, the results for each concentration of oxytocin are given as the mean \pm SEM. The values for time to doubling and time to peak level of cAMP were obtained by interpolation. 
was followed by a significant increase in the SCC beginning at approximately $2.5 \mathrm{~min}$. The rise in SCC was sustained until a peak level was reached 12 min following the addition of hormone. The measurements of tissue cAMP in the matching hemi-bladder show that the levels of nucleotide were increased by the end of $2 \mathrm{~min}$; the peak level of cAMP was attained at $4 \mathrm{~min}$, when the SCC was only entering the rising phase. The tissue nucleotide levels then began to fall so that the hormoneinduced increment in cAMP had already decayed significantly before the maximum hormonal effect upon sodium transport was expressed. A similar relationship existed between tissue cAMP concentrations and hormone-induced sodium transport at each suprathreshold concentration of oxytocin studied (Table I).

Inspection of the responses of tissue cAMP and sodium flux to hormone reveal several noteworthy points. There is a direct relationship between the maximum cAMP level attained and the peak increment in sodium flux (Table I). Doubling of the basal cAMP level seemed to correspond to the onset of the hormone-induced increment in sodium transport. Coincidence of the increment in sodium transport with the doubling of basal cAMP suggests a threshold level to which tissue cAMP must be raised in order to elicit a physiologic response (10). This conclusion is supported by the effects upon the tissue of 1.25 and $2.5 \times 10^{-0} \mathrm{M}$ oxytocin : tissue cAMP was increased by 65,81 , and $98 \%$ (exps. 1 , 2 , and 3 ), but there was no evident effect upon sodium
Figure 2 The oxytocin-induced $\left(10^{-8} \mathrm{M}\right)$ rise in cAMP levels in isolated mucosal cells of toad urinary bladder. The composition of the Ringer's solution is given in Fig. 1. The values plotted are the mean \pm SEM of four experiments.

transport. A slightly greater increase in the tissue cAMP level, 116, 121, 127, and $131 \%$ (exps. 4-7), was associated with a small $\left(5-8 \mu \mathrm{A} / 1.5 \mathrm{~cm}^{2}\right)$ increase in the SCC.

Table I shows the time interval between the estimated time of doubling of cAMP and the attainment of peak levels of cAMP is relatively invariant. This suggests a constant time interval in which hormonal activation of

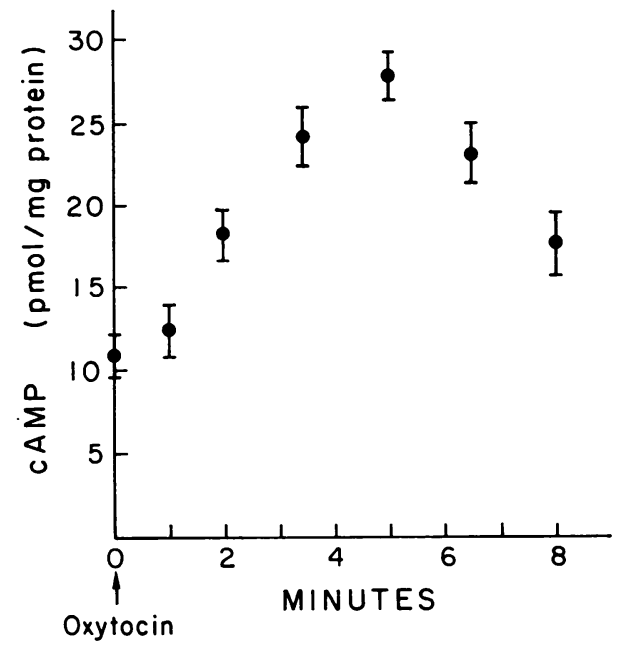

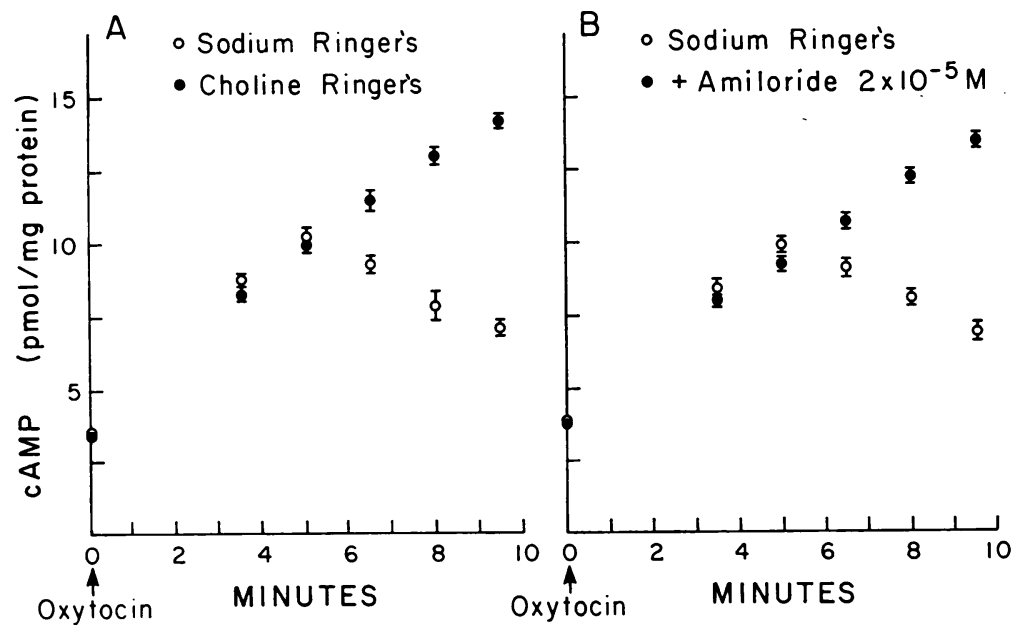

Figure 3 The effects of mucosal sodium upon tissue cAMP. $(A)$ The control hemi-bladders ( $\mathrm{O}-\mathrm{O}$ ) were incubated in Ringer's solution (composition given in Fig. 1) and the paired hemi-bladders ( - ) incubated in Ringer's solution in which the sodium was replaced by choline. Oxytocin $\left(10^{-8} \mathrm{M}\right)$ was added to both sets of hemi-bladders, and aliquots of tissue were removed at the indicated intervals for measurement of cAMP. The values given are the mean \pm SEM of four experiments. $(B)$ Control hemi-bladders were incubated in Ringer's solution and paired hemi-bladders in Ringer's solution containing amiloride $\left(1.3 \times 10^{-6} \mathrm{M}\right)$. Oxytocin $\left(10^{-8} \mathrm{M}\right)$ was added to both sets of hemi-bladders, and aliquots of tissue were removed at the indicated intervals for measurement of cAMP. The values given are the mean $\pm S E M$ $(n=4)$. 
adenylate cyclase is the predominant determinant of tissue cAMP levels, although secondary effects on phosphodiesterase activity can not be discounted. The differential maximal stimulation elicited by different hormone concentrations is thus reflected in the rate of increase of tissue cAMP, not necessarily an increased period during which hormone is effective. The possibility of a relatively constant period of time in which hormone stimulates adenylate cyclase is supported by our observation that the cAMP levels do not plateau but decay immediately from their peak values at rates seemingly independent of hormone concentration. We also observed that the greater the peak cAMP concentration attained, the longer the SCC plateau was sustained. This may be due to the greater time required for cAMP levels to fall below the apparent threshold concentration (see Fig. 1). We would speculate, therefore, that one important parameter for sustaining sodium transport is that period of time during which the tissue cAMP is maintained above the critical threshold level; this time, in turn, is related to the amount of cAMP synthesized during the brief interval in which adenylate cyclase activity is evidently enhanced by oxytocin. To assure that the changes in tissue cAMP reflected the effects of hormone upon nucleotide levels in the mucosal epithelium, we studied the effects of oxytocin $\left(2 \times 10^{-8} \mathrm{M}\right)$ upon isolated mucosal cells. Fig. 2 shows the rise in cAMP follows a time course similar to that in the whole tissue.

Bär, Hechter, Schwartz, and Walter (11) have shown that the synthesis of cAMP by toad bladder membranes is linear for 20 min following stimulation with oxytocin. It appears that the brief synthesis of cAMP we observe in the intact tissue reflects control mechanisms that are lost on fractionation of the tissue. Dousa reported that hormone stimulation of adenylate cyclase in renal medullary membranes is diminished with increasing concentration of sodium chloride (12). Our evidence that (a) the termination of hormonal stimulation of adenylate cyclase seems to occur at a fixed time after the cAMP levels are doubled and $(b)$ the estimated doubling time corresponds closely with the enhancement of SCC (sodium transport), coupled with Dousa's findings, led us to examine the possibility that the activity of the adenylate cyclase may be regulated by the influx of sodium into the mucosal cells. Tissue cAMP levels were measured in paired hemi-bladders, one incubated in sodium Ringer's as described above, the other in choline Ringer's. As shown in Fig. 3, the cAMP initially increased at similar rates in both preparations, but in the sodium-free tissue the increase was sustained during the period of observation. To rule out the possibility that this effect was due to choline, we examine the same response when the bladder was incubated in sodium
Ringer's containing amiloride, a potent inhibitor (13) of sodium influx at the mucosal surface. The results were almost identical to those in choline. We suggest, therefore, that intracellular sodium plays a servoregulatory role in the responsiveness of toad bladder adenylate cyclase to neurohypophyseal hormones.

\section{ACKNOWLEDGMENTS}

This study was supported by U. S. Public Health Service Grant AM-15205 and by a Grant-in-Aid from the American Heart Association. Mary N. Linker provided superb technical assistance.

\section{REFERENCES}

1. Sutherland, E. W., I. Øye, and R. W. Butcher. 1965. The action of epinephrine and the role of the adenyl cyclase system in hormone action. Recent Prog. Horm. Res. $21: 623$.

2. Sutherland, E. W., G. A. Robison, and R. W. Butcher. 1968. Some aspects of the biological role of adenosine 3',5'-monophosphate (cyclic AMP). Circulation. 37: 279.

3. Bentley, P. J. 1958. The effects of neurohypophysial extracts on water transfer across the wall of the isolated urinary bladder of the toad Bufo marinus. J. Endocrinol. 17 : 201.

4. Leaf, A., J. Anderson, and L. B. Page. 1958. Active sodium transport by the isolated toad bladder. J. Gen. Physiol. 41 : 657.

5. Orloff, J., and J. S. Handler. 1962. The similarity of effects of vasopressin, adenosine $3^{\prime}, 5^{\prime}$-phosphate (cyclic AMP) and theophylline on the toad bladder. J. Clin. Invest. $41: 702$.

6. Handler, J. S., R. IV. Butcher, E. W. Sutherland, and J. Orloff. 1965. The effect of vasopressin and theophylline on the concentration of adenosine $3^{\prime}, 5^{\prime}$-phosphate in the urinary bladder of the toad. J. Biol. Chem. 240: 4524.

7. Grahame-Smith, D. G., R. W. Butcher, R. L. Ney, and E. W. Sutherland. 1967. Adenosine 3',5'-monophosphate as the intracellular mediator of the action of adrenocorticotropic hormone on the adrenal cortex. J. Biol. Chem. 242: 5535.

8. Ussing, H. H., and K. Zerahn. 1951. Active transport of sodium as the source of electric current in the shortcircuited isolated frog skin. Acta Physiol. Scand. 23: 110.

9. Steiner, A. L., D. M. Kipnis, R. Utiger, and C. W. Parker. 1969. Radioimmunoassay for the measurement of adenosine $3^{\prime}, 5^{\prime}$-cyclic phosphate. Proc. Natl. Acad. Sci. U.S. A. $64: 367$.

10. Eggena, P., I. L. Schwartz, and R. Walter. 1970. Threshold and receptor reserve in the action of neurohypophyseal peptides. J. Gen. Physiol. 56: 250.

11. Bär, H. P., O. Hechter, I. L. Schwartz, and R. Walter. 1970. Neurohypophyseal hormone-sensitive adenyl cyclase of toad urinary bladder. Proc. Natl. Acad. Sci. U.S.A. $67: 7$.

12. Dousa, T. P. 1972. Effect of renal medullary solutes on vasopressin-sensitive adenyl cyclase. Am. J. Physiol. 222: 657 .

13. Bentley, P. J. 1968. Amiloride: a potent inhibitor of sodium transport across the toad bladder. J. Physiol. (Lond.) $195: 317$. 